\title{
Pengaruh Variasi Arus Pulsed Current, Continuous Current, dan Flowrate Gas Pelindung Argon Terhadap Kekerasan dan Struktur Mikro dengan Metode Tungsten Inert Gas (TIG)
}

\author{
Priagung Surya Binathara, Wikan Jatimurti, dan Alvian Toto Wibisono \\ Departemen Teknik Material, Fakultas Teknologi Industri \\ Institut Teknologi Sepuluh Nopember (ITS) \\ E-mail: wikan@mat-eng.its.ac.id
}

\begin{abstract}
Abstrak-Paduan Tembaga-Nikel Material 90/10 CuNi merupakan salah satu material utama pemakaiannya di bidang kemaritiman, karena sifatnya yang tahan terhadap korosi baik. Paduan ini dapat disambung dengan metode las TIG. Parameter pengelasan yang tepat dengan metode las TIG dibutuhkan agar meghasilkan las yang baik. Penelitian pengelasan ini dilakukan dengan metode TIG dengan parameter variasi arus continuous current 100 Ampere, pulsed current $3 \mathrm{~Hz}$, pulsed current $5 \mathrm{~Hz}$ dan flowrate gas pelindung argon 8 L/menit 12 L/menit, dan 16 L/menit/ Pengujian yang dilakukan pada penelitian ini adalah uji makro, uji komposisi kima, uji XRD, uji Mikro, dan uji kekerasan menggunakan Microvickers. Dari hasil peneltian fasa yang terbentuk setelah pengelasan adalah $\alpha \mathrm{Cu}$. Struktur mikro yang terbentuk pada bagian weld metal adalah dendritik sedangkan pada bagian base metal adalah poligonal. Seiring meningkatnya flowrate gas pelindung argon, kekerasan semakin meningkat, dan pengelasan menggunakan arus pulsed current memiliki kekerasan lebih tinggi jika dibandiingkan dengan arus continous current. Nilai kekerasan tertinggi dihasilkan pada pengelasan variasi arus pulsed current $5 \mathrm{~Hz}$ dan flowrate gas pelindung argon $16 \mathrm{~L} /$ menit dengan nilai kekerasan $118 \mathrm{HV}$.
\end{abstract}

Kata Kunci-CuNi 90/10, TIG, Pulsed Current, Flowrate.

\section{PENDAHULUAN}

$\mathrm{T}$ EMBAGA dan paduannya merupakan salah satu material yang digunakan didalam berbagai aplikasi perindustrian, salah satunya pada industri perkapalan. Tembaga digunakan pada sistem perpipaan air laut, karena sifat tahan korosinya, sifat tahan terhadap laju alir laut yang tinggi, tahan termal yang baik serta kemampuan bentuk yang baik. Tembaga adalah salah satu logam yang secara alami ditemukan dalam bentuknya yang murni, tetapi bentuk yang murni tersebut memiliki kelemahan yaitu sifatnya yang lunak. Oleh karena itu dilakukan proses paduan tembaga dengan logam lain, seperti seng yang bisa menjadi kuningan, dan alumunium atau timah yang bisa membentuk perunggu dan nikel untuk meningkatkan sifat mekaniknya[1]. Paduan tembaga yang paling banyak digunakan untuk sistem perpipaan adalah paduan tembaga nikel atau yang sering disebut dengan cupronickel. Terdapat dua macam paduan tembaga nikel yang digunakan pada instalasi perpipaan air laut, yaitu CuNi 90/10 dengan komposisi tembaga 90\% dan nikel 10\%, serta CuNi 70/30 dengan komposisi 70\% tembaga dan 30\% nikel, namun yang paling digunakan adalah paduan
CuNi 90/10, karena penggunaanya yang bisa didesain pada kecepatan aliran rendah maupun aliran tinggi, serta bisa didesain dengan diameter yang lebih kecil sehingga paduan CuNi 90/10 lebih ekonomis[2].

Pipa CuNi 90/10 dapat disambung dengan berbagai macam metode pengelasan, salah satunya menggunakan metode TIG. Pengelasan adalah ikatan metalurgi pada sambungan logam atau logam paduan yang dilaksanakan dalam keadaan lumer atau cair yang diakibatkan oleh energi panas, baik disertai tekanan maupun tanpa tekanan[3]. Tungsten Inert Gas (TIG) adalah pengelasan menggunakan elektroda tungsten yang tidak terumpan untuk satu kutub dari busur yang terlindungi dengan gas inert. Adanya gas inert sebagai pelindung yang berfungsi untuk melindungi elektroda dan weld pool serta untuk menstabilkan busur listrik[4].

Pada penelitian sebelumnya telah dilakukan analisis untuk mengetahui pengaruh variasi arus pulsed current pada pengelasan CuNi 70/30 terhadap struktur mikro dan sifat kekerasan[5]. Juga telah dilakukan analisis pengaruh dari flowrate gas pelindung terhadap struktur mikro dan sifat kekerasannya[6].

Pulsed Current Welding adalah teknik pengelasan yang dikembangkan sejak tahun 1950 dimana terjadi perubahan arus secara siklik dari level tertinggi menuju level arus terendah dengan frekuensi tertentu yang bisa diatur. Ketika berada di level arus tertinggi, arus akan memberikan efek penetrasi dan kontur bead yang merata, sedangkan ketika berada pada level arus terendah, arus berfungsi untuk menstabilkan busur listrik (arc), sehingga busur mendifusikan logam lebih efisien. Teknik pengelasan ini juga meminimalisasi panas yang terbuang karena konduksi ketika dilakukan pengelasan arus secara kontinu. Dibandingkan dengan teknik pengelasan arus secara kontinu, energi panas yang dibutuhkan untuk melelehkan (melting) logam hanya terjadi ketika pada level arus tertinggi, sehingga memungkinkan panas yang menuju ke base metal lebih sedikit sehingga heat affectected zone (HAZ) menjadi lebih sempit. Beberapa keuntungan dari pengelasan pulsed current TIG adalah membuat hasil dari bead contour menjadi lebik baik, mengurangi tegangan sisa, mengurangi distorsi, menjadikan hasil grainsize di fusion zone menjadi lebih merata, mengontrol segregasi, mengontrol penetrasi, mengurangi rentang gap width, dan mengontrol profil weld pool. Semua keuntungan tersebut memberikan dampak sifat mekanik dari hasil lasan yang semakin baik. 
Gas Pelindung digunakan dalam pengelasan TIG untuk mencegah kontaminasi dengan lingkungan atmosfer pada logam lasan. Gas yang sering dipakai pada pengelasan TIG adalah gas Argon yang memiliki potensial ionisasi yang rendah, lebih berat dari udara, sehingga menyediakan perlindungan yang bagus ketika pengelasan pada weldpool[7]. Gas pelindung memiliki efek terhadap struktur mikro dan kekerasan karena flowrate gas pelindung akan berdampak pada stabilitas busur listrik[8].

Berdasarkan uraian diatas, dilakukan penelitian yang bertujuan untuk menganalisis pengaruh arus continuous current, pulsed current, dan flowrate gas pelindung argon terhadap struktur mikro pada hasil las CuNi 90/10 dengan menggunakan metode TIG serta menganalisis pengaruh arus continuous current, pulsed current, dan flowrate gas pelindung terhadap distribusi kekerasan pada hasil las $\mathrm{CuNi}$ 90/10 dengan menggunakan metode TIG.

\section{METODE PENELITIAN}

\section{A. Preparasi Material}

Preparasi dilakukan dengan memotong pipa material uji CuNi 90/10 dengan tebal $2.3 \mathrm{~mm}$ menjadi beberapa potongan dengan diameter $101.6 \mathrm{~mm}$ dan panjang 50mm Kemudian membersihkan daerah spesimen uji yang nantinya akan dilakukan pengelasan TIG. Pembersihan spesimen uji ini dengan dua cara, yang pertama dengan dibersihkan secara mekanik yakni dengan kertas amplas (SiC paper) dan yang kedua dengan kimiawi yakni dengan aceton. yang bertujuan untuk menghilangkan kontaminasi pengotor ketika pengelasan. Kemudian melakukan pengelasan secara langsung menggunakan metode TIG

\section{B. Variabel Penelitian}

Pada penelitian ini menggunakan variasi arus continuous current, pulsed current dan flowrate gas pelindung argon. Variasi arus yang digunakan adalah continuous current 100A, pulsed current $3 \mathrm{~Hz}$, pulsed current $5 \mathrm{~Hz}$. Sedangkan variasi flowrate gas pelindung argon yang digunakan adalah $8 \mathrm{~L} /$ menit, $12 \mathrm{~L} /$ menit dan $16 \mathrm{~L} /$ menit.

\section{Spesifikasi Bahan}

1) Material Pipa CuNi $90 / 10$

Spesifikasi dari pipa CuNi 90/10 yang digunakan pada penelitian kali ini ditunjukkan pada Tabel 1, Tabel 2, dan Tabel 3.

Tabel 1.

Dimensi Pipa CuNi 90/10

\begin{tabular}{ll}
\hline \hline Spesifikasi & Ukuran \\
\hline Panjang & $5 \mathrm{~cm}$ \\
Tebal & $2.5 \mathrm{~mm}$ \\
Diameter & $10.16 \mathrm{~cm}$ \\
\hline \hline
\end{tabular}

Tabel 2.

Sifat Mekanik CuNi

\begin{tabular}{ccc}
\multicolumn{3}{c}{ Sifat Mekanik CuNi } \\
\hline \multicolumn{3}{c}{ Sifat Mekanik } \\
\hline Tensile Strenght(MPa) & \% elongasi & Hardness (HV) \\
350 & 35 & 60 \\
\hline \hline
\end{tabular}

Tabel 3.

Kebutuhan Komposisi Pipa CuNi 90/10

\begin{tabular}{ll}
\hline \hline \multicolumn{1}{c}{ Unsur } & Komposisi \\
\hline Tembaga $(\mathrm{Cu})$ & $>86.5$ \\
Nikel $(\mathrm{Ni})$ & $9-11$ \\
Besi $(\mathrm{Fe})$ & $1-1.2$
\end{tabular}

\begin{tabular}{ll} 
Mangan (Mn) & 1 \\
Seng (Zn) & 0.5 \\
Karbon (C) & 0.05 \\
Sulfur (S) & 0.02 \\
Timbal (Pb) & 0.01 \\
\hline \hline
\end{tabular}

2) Filler Metal ERCuNi

Spesifikasi dari filler metal ERCuNi yang digunakan pada penelitian kali ini ditunjukkan pada Tabel 4.

Tabel 4.

Dimensi Filler Metal ERCuNi

\begin{tabular}{ll}
\hline Spesifikasi & Ukuran \\
\hline Panjang & $300 \mathrm{~mm}$ \\
Diameter & $1.6 \mathrm{~mm}$ \\
\hline \hline
\end{tabular}

Tabel 5.

Kebutuhan Komposisi Filler Metal ERCuNi

\begin{tabular}{ll}
\hline \hline \multicolumn{1}{c}{ Unsur } & Komposisi \\
\hline Tembaga (Cu) & Seimbang \\
Nikel (Ni) & 29.0 \\
Besi (Fe) & $0.4-0.75$ \\
Mangan (Mn) & $1.0-2.5$ \\
Silikon (Si) & 0.5 \\
Karbon (C) & 0.05 \\
Sulfur (S) & 0.015 \\
Titanium (Ti) & 0.5 \\
\hline \hline
\end{tabular}

3) Gas Argon

Spesifikasi dari gas argon yang digunakan untuk gas pelindung pada penelitian kali ini ditunjukkan pada Tabel 6.

Tabel 6.

Spesifikasi Kebutuhan Gas Argon

\begin{tabular}{cc}
\hline \hline Jenis & Ukuran \\
\hline Presentase Gas Argon & $99.99 \%$ \\
\hline \hline
\end{tabular}

\section{Preparasi Pengelasan}

Salah satu hal terpenting yang menentukan keberhasilan pengelasan adalah preparasi sebelum pengelasan. Langkahlangkah preparasi sebelum proses pengelasan adalah mempersiapkan material pipa CuNi 90/10, filler metal dan gas argon yang telah sesuai dengan spesifikasi. Setelah itu memotong pipa CuNi 90/10 dengan ukuran panjang $\mathrm{x}$ diameter sebesar $50 \mathrm{~mm}$ x $101.6 \mathrm{~mm}$ sebanyak 9 pasang. Kemudian membersihkan secara mekanik dengan menggunakan kertas amplas dan secara kimiawi membersihkan menggunakan dengan aceton. Kemudian mempersiapkan filler metal dan gas argon di ruang pengelasan. Untuk parameter pengelasan bisa dilihat pada Tabel 7 dibawah.

Tabel 7.

Parameter Pengelasan yang Dibutuhkan untuk Pengelasan Pipa CuNi 90/10

\begin{tabular}{|c|c|c|c|}
\hline \multicolumn{2}{|c|}{ Constant Current } & \multicolumn{2}{|c|}{ Pulsed Current } \\
\hline Voltage & $16 \mathrm{~V}$ & Voltage & $16 \mathrm{~V}$ \\
\hline Flow Rate & $\begin{array}{ll}8 \mathrm{~L} / \text { menit, } & 12 \\
\mathrm{~L} / \mathrm{menit} & 16 \\
\mathrm{~L} / \mathrm{menit} & \end{array}$ & Flow Rate & $\begin{array}{l}8 \text { L/menit, } 12 \\
\text { L/menit, } \\
\text { L/menit }\end{array}$ \\
\hline Current & $100 \mathrm{~A}$ & Peak Current & $133,3 \mathrm{~A}$ \\
\hline Welding speed & $10 \mathrm{~cm} / \mathrm{menit}$ & $\begin{array}{l}\text { Base Current } \\
\text { Pulse Frequency } \\
\text { Welding speed }\end{array}$ & $\begin{array}{l}66,7 \text { A } \\
3 \mathrm{hz}, 5 \mathrm{hz} \\
10 \mathrm{~cm} / \mathrm{menit}\end{array}$ \\
\hline
\end{tabular}

\section{E. Proses Pengelasan}

Proses pengelasan dengan cara mengelas dengan pengelasan TIG dengan variasi arus dan flowrate gas pelindung argon yang telah ditetapkan pada tiap spesimen. Pada saat pengelasan benda kerja dialiri dengan backing gas 
berupa gas argon 99.99\% dengan laju alir 8L/m dengan tujuan untuk meminimalisir adanya cacat las. Preheat dan post heat tidak dilakukan pada pengelasan pipa CuNi 90/10.

\section{HASIL DAN DISKUSI}

\section{A. Hasil Pengamatan Makro}

Hasil pengamatan makro dilakukan setelah proses etsa pada masing-masing spesimen menggunakan etsa nomor 40 berdasarkan ASTM E-407. Berdasarkan hasil pengamatan makro, dapat terlihat daerah weld metal, fusion line dan daerah base metal. Selain itu terdapat beberapa cacat yang dialami oleh masing-masing spesimen. Untuk hasil pengamatan makro dapat dilihat pada Gambar 1 dibawah ini. CC menunjukkan pulsed current, PC menunjukkan pulsed current, FG menunjukkan flowrate gas pelindung argon.

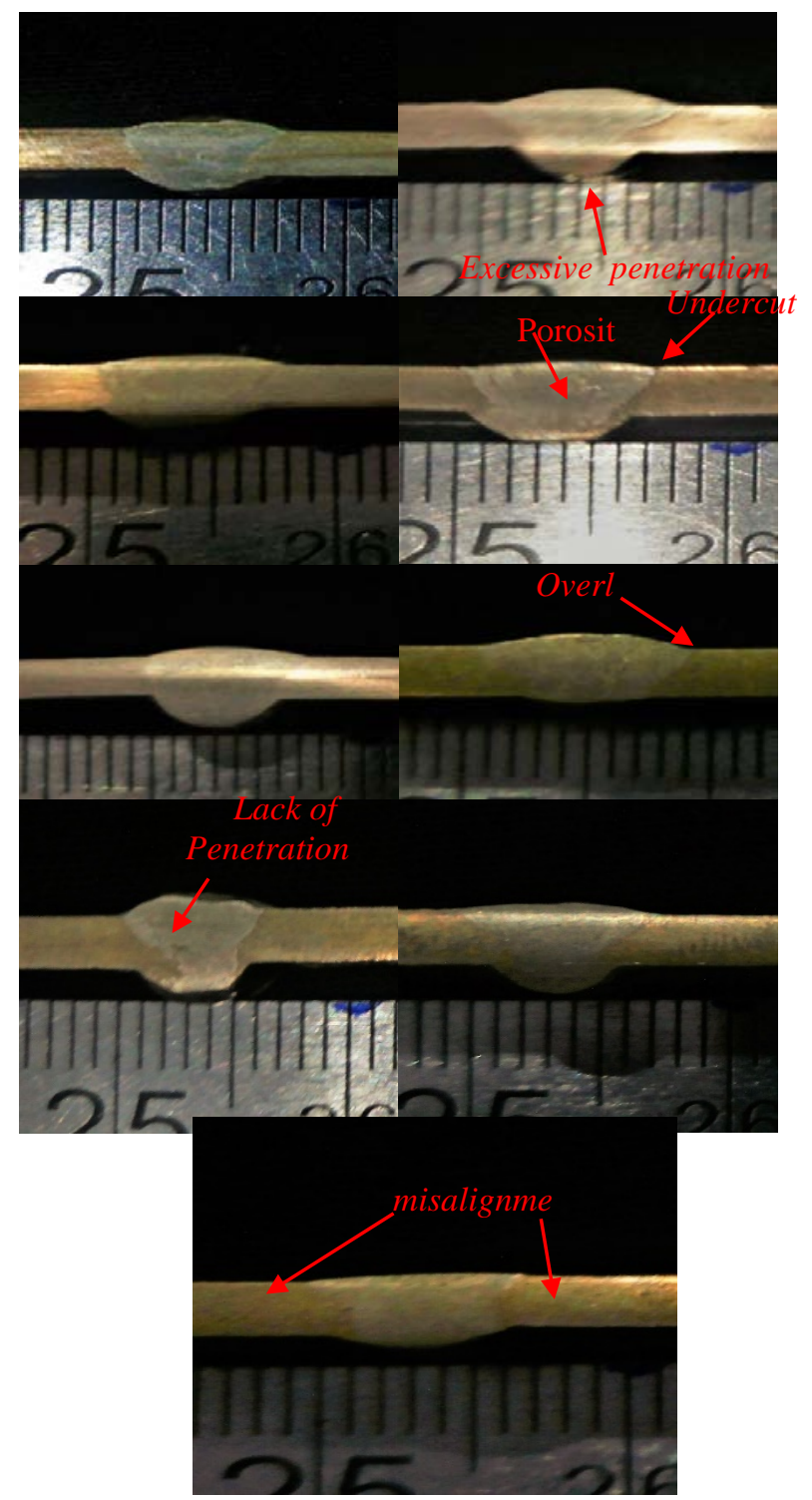

Gambar 1. Hasil Pengamatan Makro Pengelasan CuNi 90/10 (a) FG 8L/menit-CC (b) FG 8L/menit-PC 3 Hz (c) FG 8L/menit-PC 5 Hz (d) FG 12 L/menit-CC (e) FG 12 L/menit-PC 3 Hz (f) FG 12L/menit-PC 5 Hz (g) FG 16 L/menit-CC, (h) FG 16L/menit-PC 3 Hz (i) FG 16 L/menit-PC 5 Hz

Pada hasil pengamatan makro yang ditampilkan pada Gambar 1 dapat dilihat perbedaan pada daerah weld metal dan base metal secara visual. Daerah HAZ tidak terbentuk pada pengelasan ini sehingga secara visual tidak terlihat dan hanya terlihat bagian fusion line.
Selain dengan pengamatan makro juga dilakukan pengukuran lebar dan tinggi weld metal sehingga didapatkan ukuran secara kuantitatif untuk melihat hasil pengelasan yang terbaik. Pengukuran lebar dan tinggi pengelasan menggunakan mikrometer sekrup Sedangkan untuk menghitung luasan menggunakan aplikasi ImageJ. Hasil pengukuran lebar dan tinggi serta luasan dari weld metal dapat dilihat pada Gambar 2.

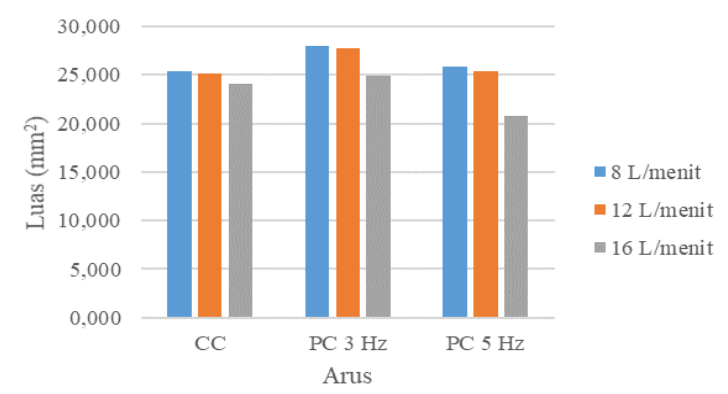

Gambar 2. Grafik Hasil Pengukuran Luas Weld Metal

Dari hasil tersebut dapat terlihat bahwa semakin tinggi flowrate gas pelindung argon yang dihasilkan, maka luas weld metal yang dihasilkan semakin kecil, hal ini karena semakin tinggi flowrate gas pelindung argon pada saat pengelasan, akan membuat busur listrik (arc) semakin stabil, busur yang semakin stabil ini menghasilkan panas yang lebih tinggi sehingga weld metal yang dihasilkan semakin halus. Hasil dari pengelasan yang semakin halus akan menyebabkan dimensi lebar dan tinggi weld metal yang dihasilkan semakin kecil, sehingga luas dari weld metal yang dihasilkan semakin kecil pula.diberikan[8].

\section{B. Hasil Pengujian Komposisi}

Komposisi base metal CuNi 90/10 telah diuji dengan menggunakan spectrometer gun. Hasil pengujian komposisi pada base metal dan filler metal dapat dilihat pada Tabel 8.

Tabel 8

Perbandingan Hasil Pengujian Komposisi Base Metal dan Filler Metal

\begin{tabular}{cccccc}
\hline \hline Jenis & Unsur & Komposisi & Jenis & Unsur & Komposisi \\
\hline & $\mathrm{Cu}$ & 86.32 & & $\mathrm{Cu}$ & $\mathrm{Bal}$ \\
& $\mathrm{Ni}$ & 10.11 & & $\mathrm{Ni}$ & 29 \\
& $\mathrm{Zn}$ & 1.68 & & $\mathrm{Ti}$ & 0.5 \\
Base Metal & $\mathrm{Mn}$ & 0.58 & Filler Metal & $\mathrm{Mn}$ & $1-2.5$ \\
CuNi 90/10 & $\mathrm{Fe}$ & 1.11 & ERCuNI & $\mathrm{Fe}$ & $0.4-0.8$ \\
& $\mathrm{Co}$ & 0.07 & & $\mathrm{Si}$ & 0.5 \\
& $\mathrm{Zr}$ & 0.08 & & $\mathrm{Zn}$ & - \\
& $\mathrm{Pb}$ & 0.01 & & $\mathrm{P}$ & 0.2 \\
\hline \hline
\end{tabular}

Berdasarkan hasil pengujian diatas maka dapat dikatakan bahwa material pipa CuNi 90/10 dan filler metal ERCuNi yang digunakan untuk pengelasan kali ini telah sesuai dengan standar.

\section{Hasil Pengujian XRD}

Pengujian XRD dilakukan untuk mengetahui fasa atau senyawa yang terbentuk selama proses pengelasan terjadi. Pengujian ini dilakukan pada daerah weld metal. Hasil pengujian XRD ditunjukkan pada Gambar 3. 


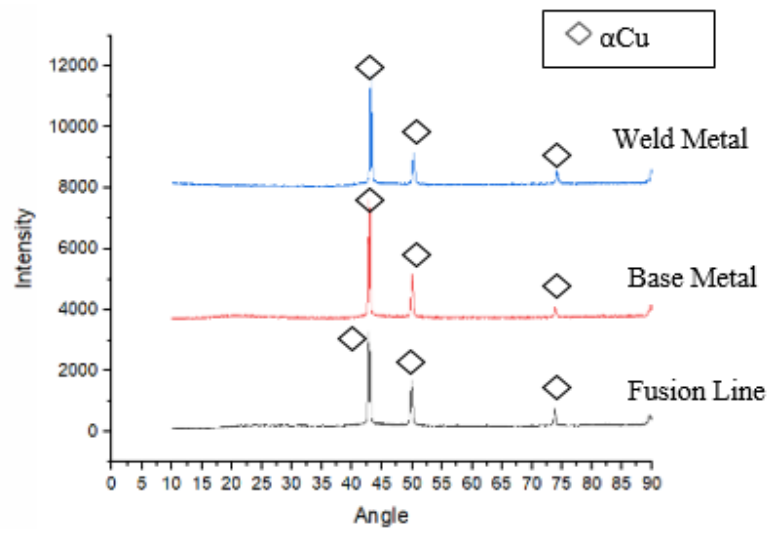

Gambar 3. Hasil Pengujian XRD Hasil Las CuNi 90/10

Peak yang muncul menunjukkan peak $\mathrm{Cu}$. Peak Ni tidak muncul pada hasil pengujian XRD. Hal ini disebabkan karena unsur Ni larut sempurna ke dalam unsur $\mathrm{Cu}$. Struktur kristal atom $\mathrm{Ni}$ memiliki kesamaan dengan atom $\mathrm{Cu}$ yaitu Face Centered Cubic, memiliki ukuran atom yang relatif sama, afinitas dan Elektronegativitas yang tidak telalu jauh. Jika dipadukan, atom Ni menggantikan atom $\mathrm{Cu}$ pada struktur kristal sehingga membentuk larutan padat substitusional. Larutan padat substitusi yang terbentuk tersebut adalah fasa $\alpha$. Di dalam fasa $\alpha$ tersebut, unsur Ni merupakan unsur yang terlarut di dalam unsur pelarut $\mathrm{Cu}$. Oleh karena itu, fasa yang muncul di hasil pengujian XRD ini adalah fasa $\alpha \mathrm{Cu}$ karena unsur $\mathrm{Cu}$ memiliki komposisi yang lebih banyak sebagai pelarut[9].

\section{Hasil Pengujian Struktur Mikro}

Pengamatan struktur mikro dilakukan setelah melakukan proses etsa pada masing-masing specimen dengan menggunakan etsa nomor 40 pada ASTM E-407 dengan menggunakan mikroskop optik pada daerah weld metal, fusion line dan base metal yang ditunjukkan pada Gambar 412.

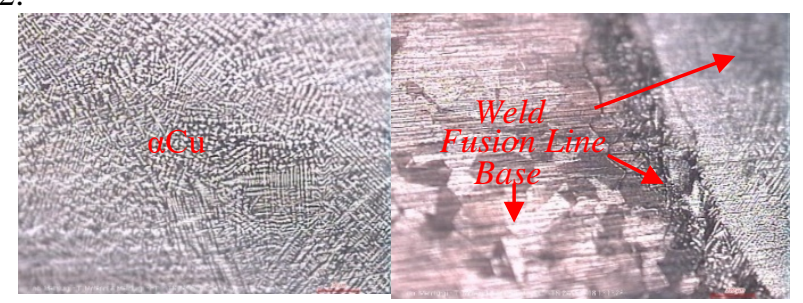

Gambar 4. Hasil Pengamatan Struktur Mikro CuNi 90/10 pada Variasi Arus CC dan FG 8 L/menit (a)Weld Metal (b)Fusion Line

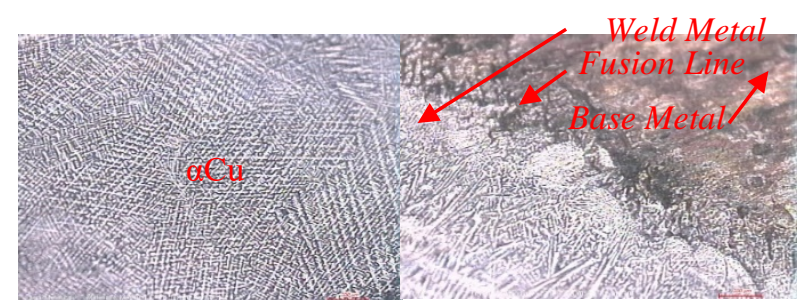

Gambar 5. Hasil Pengamatan Struktur Mikro CuNi 90/10 pada Variasi Arus CC dan FG 12 L/menit (a)Weld Metal (b)Fusion Line

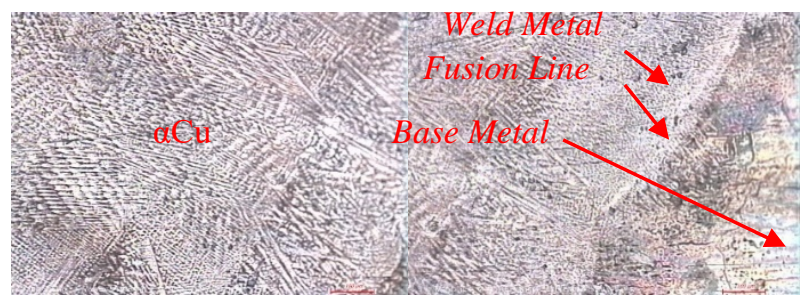

Gambar 6. Hasil Pengamatan Struktur Mikro CuNi 90/10 Pada Variasi Arus CC dan FG 16 L/menit (a)Weld Metal (b)Fusion Line

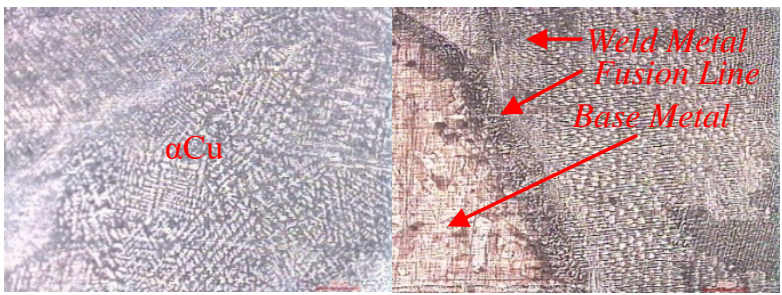

Gambar 7. Hasil Pengamatan Struktur Mikro CuNi 90/10 pada Variasi Arus PC 3 Hz dan FG 8 L/menit (a)Weld Metal (b)Fusion Line

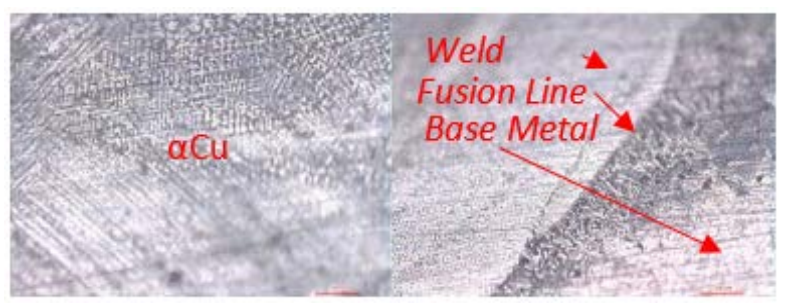

Gambar 8. Hasil Pengamatan Struktur Mikro CuNi 90/10 pada Variasi Arus PC 3 Hz dan FG 12 L/menit (a)Weld Metal (b)Fusion Line

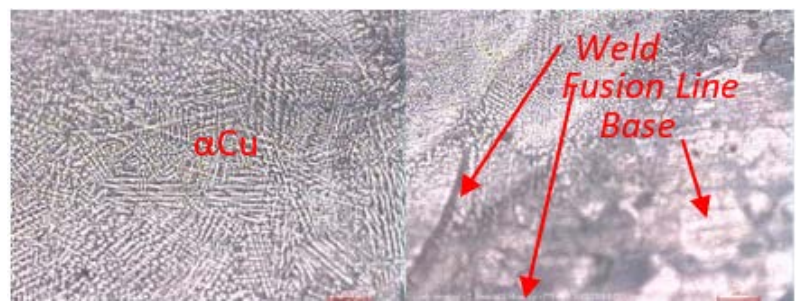

Gambar 9. Hasil Pengamatan Struktur Mikro CuNi 90/10 pada Variasi Arus PC 3 Hz dan FG 16 L/menit (a)Weld Metal (b)Fusion Line

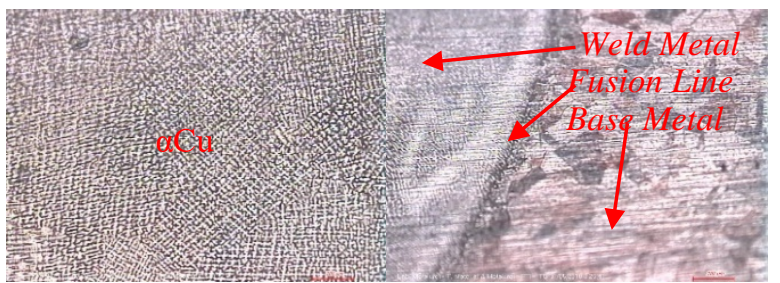

Gambar 10. Hasil Pengamatan Struktur Mikro CuNi 90/10 pada Variasi Arus PC 5 Hz dan FG 8 L/menit (a)Weld Metal (b)Fusion Line

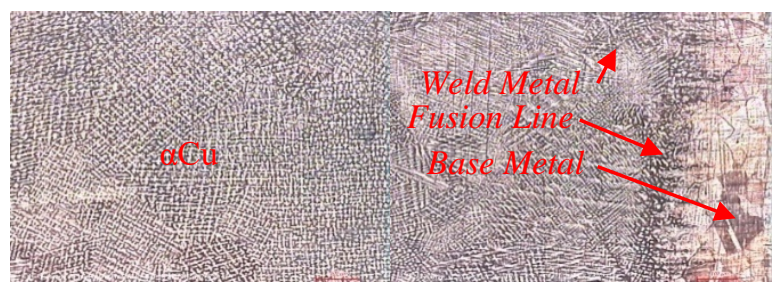

Gambar 11. Hasil Pengamatan Struktur Mikro CuNi 90/10 pada Variasi Arus PC 5 Hz dan FG 12 L/menit (a)Weld Metal (b)Fusion Line

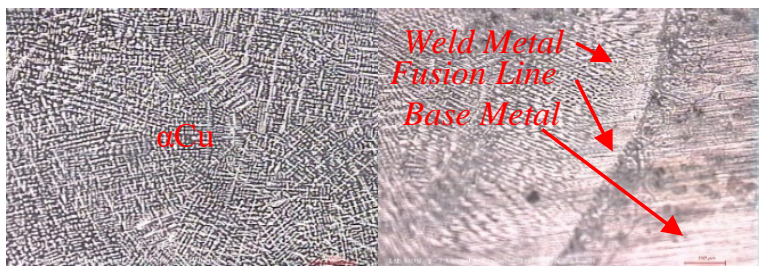

Gambar 12. Hasil Pengamatan Struktur Mikro CuNi 90/10 pada Variasi Arus PC 5 Hz dan FG 16 L/menit (a)Weld Metal (b)Fusion Line

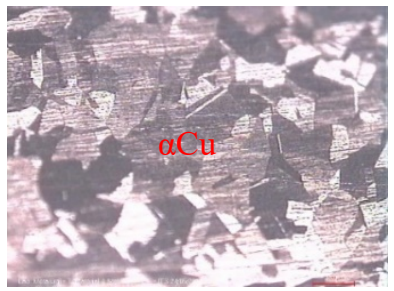

Gambar 13. Hasil Pengamatan Struktur Mikro CuNi 90/10 pada base metal 
Gambar 4-12 (a) merupakan hasil pengamatan struktur mikro pengelasan CuNi 90/10 yang berad di weld metal. Fasa terbentuk adalah $\alpha \mathrm{Cu}$, sesuai dengan hasil pengujian XRD. Pada ukuran butir weld metal $\alpha \mathrm{Cu}$ yang terbentuk adalah berbentuk dendritik dan yang terbentuk pada base metal berbentuk poligonal. Fasa $\alpha \mathrm{Cu}$ dendritik yang terdapat di bagian weld metal terbentuk karena setiap fasa yang terbentuk harus menyesuaikan komposisinya dengan migrasi atom, tetapi ketika mengalami peleburan saat fasa cair, terjadi difusi yang berlangsung relatif cepat, sehingga tidak ada kesempatan untuk meniadakan perbedaan komposisi melalui difusi, sehingga setiap butir $\alpha \mathrm{Cu}$ memiliki gradien komposisi melalui difusi, sehingga setiap butir $\alpha \mathrm{Cu}$ memiliki gradien komposisi terhadap inti yang kaya akan logam dengan titik leleh lebih tinggi yaitu Nikel, sedangkan bagia luar kaya akan logam dengan titik leleh lebih rendah yaitu tembaga. Larutan padat yang tidak merata ini disebut sebagai cored atau dendritik[10].

Gambar 4-12 (b) merupakan hasil pengamatan struktur mikro yang terdapat pada fusion line. Pada daerah ini berwarna gelap dikarenakan pertemuan pembekuan antara daerah weld metal dan base metal. Pada pengelasan CuNi 90/10 ini tidak ditemukan adanya HAZ. Tidak ditemukannya daerah HAZ ini disebabkan karena CuNi 90/10 tidak banyak mengalami perubahan fasa saat pendinginan setelah proses pengelasan. Hal ini bisa terlihat pada diagram fasa $\mathrm{CuNi}$ 90/10 yang mana fasa yang ada pada diagram tersebut hanya ada fasa cair dan padat berupa $\alpha \mathrm{Cu}$. Selain itu dari hasil kekerasan juga menunjukkan tidak adanya perubahan kekerasan yang signifikan akibat adanya panas dari proses las[11].

Gambar 4.13 adalah hasil pengamatan struktur mikro yang berada di base metal. Fasa yang terbentuk adalah $\alpha \mathrm{Cu}$ sesuai dengan pengujian XRD, dan terjadi pemerataan komposisi sehingga komposisi nikel dan tembaga merata disetiap butirnya. Sebenarnya, awal pembuatan pipa CuNi berbentuk dendritik, tetapi kemudian dilakukan pengerjaan panas yang disebut sebagai proses homogenisasi, yaitu proses dimana logam dipanaskan pada suhu tinggi (sekitar $700-800^{\circ} \mathrm{C}$ ), kemudian ditahan pada temperatur tersebut sekitar 25 jam, yang bertujuan untuk memberikan kesempatan terjadinya difusi untuk membuat struktur lebih homogen[12].

Dari hasil pengamatan struktur mikro telah dilakukan perhitungan butir untuk melihat berapa banyak butir yang terdapat dalam luasan tertentu. Perhitungan ini menggunakan metode Jeffries yang sesuai dengan ASTM E-112. Tujuan dari perhitungan butir ini adalah untuk memprediksi kekerasan dari spesimen. Untuk hasil perhitungan dengan metode jeffiries dapat dilihat pada Gambar 14.

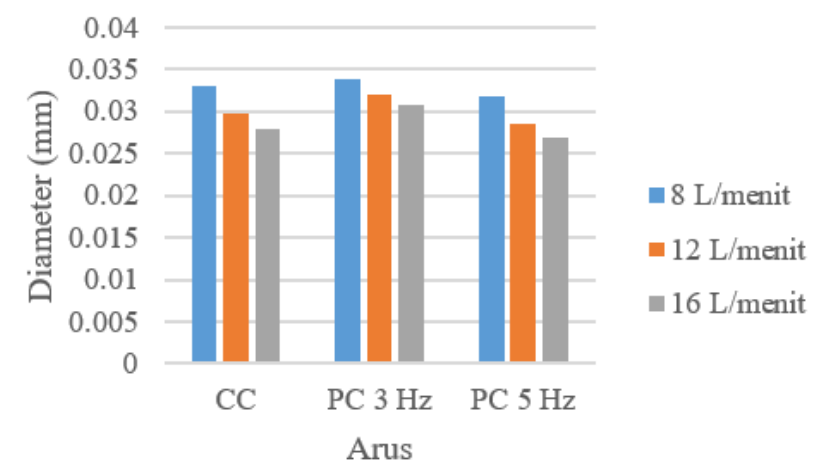

Gambar 14. Grafik Hasil Perhitungan Butir dengan Metode Jeffries Pada Weld Metal
Gambar 14 merupakan grafik perhitungan nilai Jeffries dimana semakin bertambahnya flowrate gas pelindung argon, maka diameter butir yang dihasilkan pada weld metal semakin kecil. Pada Gambar 14 dapat dibandingkan pada weld metal di tiap spesimen, bahwa spesimen dengan parameter las arus pulsed current $5 \mathrm{~Hz}$ cenderung memiliki diameter butir yang lebih kecil dibandingkan dengan spesimen dengan arus constant current 100 Ampere dan pulsed current $3 \mathrm{~Hz}$, dan dari hasil pengamatan juga terlihat bahwa butiran yang terbentuk lebih halus daripada spesimen dengan arus constant current 100 Ampere dan pulsed current $3 \mathrm{~Hz}$.

\section{E. Hasil Pengujian Kekerasan}

Pengujian kekerasan dilakukan dengan menggunakan metode Vickers menggunakan alat mikro Vickers. Pengambilan data dilakukan di 3 titik indentasi di daerah weld metal, fusion line dan base metal. Untuk mengetahui distribusi kekerasan di tiap daerah indentasi dapat dilihat pada Gambar 15.

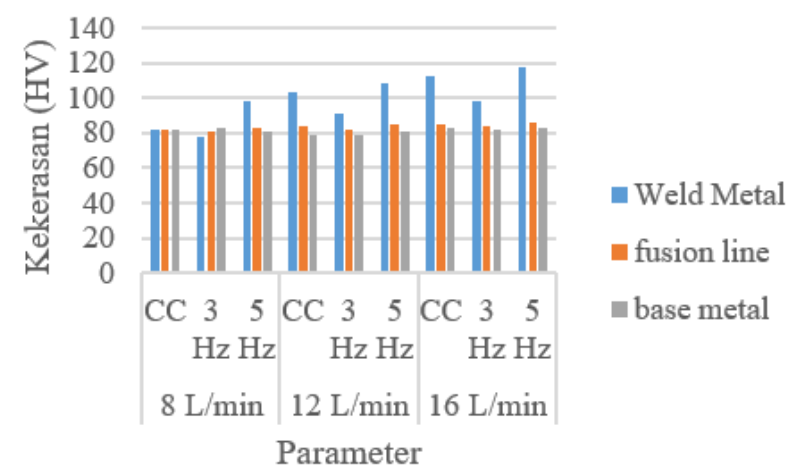

Gambar 15. Grafik Hasil Pengujian Kekerasan CuNi 90/10 pada Spesimen

Berdasarkan Gambar 15, nilai kekerasan pada weld metal, fusion line, dan base metal. Dapat dilihat bahwa seiring meningkatnya flowrate gas pelindung argon, nilai kekerasannya semakin meningkat, hal ini disebabkan karena semakin tinggi flowrate gas pelindung argon maka kestabilan dan intensitas pembentukan plasma dan temperatur busur listrik ( $a r c)$ yang dihasilkan semakin meningkat yang menyebabkan tingkat kekerasan meningkat ${ }^{[6]}$. Pada gambar tersebut menunjukkan perbandingan kekerasan pada daerah fusion line dimana seiring meningkatnya flowrate gas pelindung argon nilai kekerasan di fusion line semakin tinggi. Pada Gambar tersebut juga menunjukkan grafik perbandingan nilai kekerasan yang berada di base metal, dimana nilai kekerasan dari spesimen dengan flowrate gas pelindung argon $8 \mathrm{~L} /$ menit menuju ke $12 \mathrm{~L} /$ menit mengalami penurunan, dan meningkat lagi dari $12 \mathrm{~L} /$ menit menuju 16 L/menit.

Dari Gambar 15 juga dapat dilihat bahwa Nilai Kekerasan tertinggi yang berada di daerah weld metal dihasilkan pada pengelasan dengan flowrate gas pelindung argon 16L/menit dan arus pulsed current $5 \mathrm{~Hz}$. Kemudian spesimen yang memiliki kekerasan terendah di daerah weld metal adalah pada pengelasan dengan flowrate gas pelindung argon 8 $\mathrm{L} /$ menit dan frekuensi arus pulsed current $3 \mathrm{~Hz}$. Kekerasan bagian weld metal yang ditunjukkan pada Gambar 15 sesuai dengan besar diameter butir yang ditunjukkan oleh Gambar 14, dimana semakin kecil diameter butir pada mikrostruktur maka semakin tinggi pula kekerasan pada material tersebut. Hal ini dikarenakan semakin kecil diameter butir maka jumlah batas butir semakin meningkat, sehingga dislokasi 
sulit untuk bergerak dan material sulit untuk berdeformasi, membutuhkan energi yang tinggi untuk terjadi deformasi.

\section{KESIMPULAN}

Struktur mikro yang dihasilkan pada masing-masing pengelasan adalah $\alpha \mathrm{Cu}$. Pada weld metal struktur mikronya berupa full dendritic sedangkan pada base metal berupa polycrystalline $\alpha$-phase solid solution. Semakin tinggi frekuensi pulsed current dan flowrate gas pelindung argon menghasilkan struktur mikro yang lebih halus.

Semakin tinggi frekuensi pulsed current dan flowrate gas pelindung argon maka nilai kekerasan dari masing-masing spesimen semakin tinggi. Nilai kekerasan paling tinggi ditunjukkan oleh spesimen dengan arus pulsed current $5 \mathrm{~Hz}$ dan flowrate gas pelindung argon yaitu sebesar 118 HV.

\section{DAFTAR PUSTAKA}

[1] P. T. Gilbert, "Corrosion resisting properties of 90/10 Copper-nickeliron alloy with particular reference to offshore oil and gas applications,” Br. Corros. J., vol. 14, no. 1, pp. 20-25, Jan. 1979.

[2] J. L. Everhart, Engineering properties of nickel and nickel alloys,. New York: Plenum Press, 1971.
[3] M. I. Khan, Welding science and technology. New Delhi: New Age International (P) Ltd., Publishers, 2007.

[4] DED (German Development Service), Gas Tungsten Arc Welding Course. DED (German Development Service), 2000.

[5] M. P. Chakravarthy, "Study of microstructure and mechanical properties of $90 \% \mathrm{Cu} 10 \% \mathrm{Ni}$ alloy joints using laser beam welding," Int. J. Mech. Prod. Eng., vol. 6, no. 1, pp. 2321-2071, 2018.

[6] A. W. Prasetya, "Pengaruh debit gas pelindung dan tegangan listrik terhadap tingkat kekerasan dan struktur mikro sambungan las GMAW pada baja karbon sedang EMS-45,” Institut Teknologi Sepuluh Nopember, Surabaya, 2017.

[7] J. N. Pires, A. Loureiro, and G. Bolmsjö, Welding robots : technology, system issues and applications. London: Springer, 2006.

[8] S. E. Prasetyo, "Pengaruh kuat arus listrik dan laju alir gas pelindung terhadap struktur mikro dan kekuatan tarik-geser sambungan las tig logam tak sejenis alumunium paduan 5052-baja galvanis dengan filler Al-Si 4043,” Universitas Sebelas Maret, 2015.

[9] W. D. Callister, Materials science and engineering : an introduction, 7th ed. New York: John Wiley \& Sons, 2007.

[10] R. E. Smallman and R. J. Bishop, Metalurgi fisik modern dan rekayasa material. Jakarta: Erlangga, 2000.

[11] J. Devletian, "Flux cored arc welding of CuNi 90/10 piping with CuNi 70/30 filler metal," 2006.

[12] W. Schleich, "Application of Copper-nickel alloy UNS C70600 for seawater service," CORROSION, 2005. 